$10-1-2020$

\title{
Headwaters Fed by Subterranean Ice: Potential Climate Refugia for Mountain Stream Communities?
}

Lusha M. Tronstad

Scott Hotaling

J. Joseph Giersch

Oliver J. Wilmot

Debra S. Finn

Missouri State University

Follow this and additional works at: https://bearworks.missouristate.edu/articles-cnas

\section{Recommended Citation}

Tronstad, Lusha M., Scott Hotaling, J. Joseph Giersch, Oliver J. Wilmot, and Debra S. Finn. "Headwaters fed by subterranean ice: potential climate refugia for mountain stream communities?." BioRxiv (2020): 788273. 


\title{
Headwaters fed by subterranean ice: potential climate refugia for mountain stream communities?
}

\author{
Lusha M. Tronstad ${ }^{1, *}, \dagger$, Scott Hotaling $2, \dagger$, J. Joseph Giersch ${ }^{3}$, \\ Oliver J. Wilmot ${ }^{1}$, and Debra S. Finn ${ }^{4}$ \\ ${ }^{1}$ Wyoming Natural Diversity Database, University of Wyoming, Laramie, WY \\ ${ }^{2}$ School of Biological Sciences, Washington State University, Pullman, WA \\ ${ }^{3}$ U.S. Geological Survey, Northern Rocky Mountain Science Center, West Glacier, MT \\ ${ }^{4}$ Department of Biology, Missouri State University, Springfield, MO
}

\begin{abstract}
Near-term extirpations of macroinvertebrates are predicted for mountain streams worldwide as a warming climate drives the recession of high-elevation ice and snow. However, hydrological sources likely vary in their resistance to climate change, and thus streams fed by more resistant sources could persist as climate refugia for imperiled biota. In 2015-2016, we measured habitat characteristics and quantified macroinvertebrate community structure along 6 alpine streams in the Teton Range, Wyoming, USA. Strong differences in habitat characteristics (e.g., temperature, bed stability, conductivity) confirmed 3 major stream sources: surface glaciers, perennial snowfields, and subterranean ice. Subterranean ice-fed streams-termed "icy seeps"-appear common in the Teton Range and elsewhere, yet are globally understudied. Midges in the family Chironomidae dominated our study sites, representing $78.6 \%$ of all specimens sampled, with nematodes, caddisflies (Neothremma), and mayflies (Epeorus) also common. At the community scale, glacier- and snowmelt-fed streams differed significantly in multivariate space, with icy-seep communities intermediate between them, incorporating components of both assemblages. Because the thermal environment of subterranean ice, including rock glaciers, is decoupled from large-scale climatic conditions, we predict that icy seeps will remain intact longer than streams fed by surface ice and snow. Furthermore, our results suggest that icy seeps are suitable habitat for many macroinvertebrates occupying streams fed by vulnerable hydrological sources. Thus, icy seeps may act as key climate refugia for mountain stream biodiversity, an idea in need of further investigation.
\end{abstract}

RESUMEN.-En los arroyos de montañas a nivel mundial, se pronostica a corto plazo la erradicacion de macroinvertebrados, debido a la disminución del hielo y nieve a grandes altitudes, como consecuencia de un clima cada vez más cálido. Sin embargo, es probable que las fuentes hidrológicas varíen en su capacidad de resistencia al cambio climático, haciendo que las corrientes alimentadas por fuentes más resistentes puedan persistir y servir como refugio climático para la biota amenazada. En 2015-2016, medimos las características del hábitat y cuantificamos la estructura de la comunidad de los macroinvertebrados a lo largo de seis arroyos alpinos en la Cordillera Teton, Wyoming, EE. UU. Las marcadas diferencias en las características del hábitat (e.g. temperatura, estabilidad del lecho, conductividad) confirmaron tres fuentes principales de corrientes: glaciares superficiales, campos de nieve perennes y hielo subterráneo. Las corrientes subterráneas alimentadas por hielo, llamadas "filtraciones de hielo", parecen ser comunes en la Cordillera Teton y en otros lugares, aunque poco estudiadas en el mundo. Los mosquitos de la familia Chironomidae dominaron nuestros sitios de estudio, representando el $78.6 \%$ de todos los especímenes muestreados, junto a los nematodos, los tricópteros (Neothremma) y las efímeras (Epeorus), que también fueron comunes. A nivel comunidad, las corrientes alimentadas por glaciares y agua de deshielo difirieron significativamente en un espacio multivariante, con filtraciones de hielo entre ellas, incorporando componentes de ambos ensamblajes. Debido a que, el ambiente térmico del hielo subterráneo (incluidos los glaciares rocosos) está disociado de las condiciones climáticas a gran escala, predecimos que las filtraciones de hielo permanecerán intactas por más tiempo, que las corrientes alimentadas por el hielo de la superficie y nieve. Además, nuestros resultados indican que las filtraciones de hielo son hábitats adecuados para muchos macroinvertebrados que habitan arroyos alimentados por fuentes hidrológicas vulnerables. Por lo tanto, las filtraciones de hielo podrían actuar como refugios climáticos clave para la biodiversidad de los arroyos de montaña, una hipótesis que necesita mayor investigación.

\footnotetext{
*Corresponding author: tronstad@uwyo.edu

†Contributed equally 
The highest rates of climate change are occurring above the permanent treeline in alpine and arctic ecosystems (Bradley et al. 2006). In the Rocky Mountains, warming is proceeding 2-3 times more quickly than the global average (Hansen et al. 2005, Pederson et al. 2010), resulting in extensive loss of glaciers and long-term snowpack (Hall and Fagre 2003). Streams fed by permanent ice may exhibit short-term increases in flow as air temperatures rise and source ice melting accelerates, but eventually these streams will shift to reduced flow and warm with the potential for intermittency or drying permanently (Hotaling et al. 2017). As climate change proceeds, invertebrate diversity at the mountain range scale is predicted to decrease due to both overall loss of habitat and summit traps, where the highest-altitude species and communities have nowhere left to disperse as warmer conditions and lower-elevation communities shift upward. Biodiversity loss will be compounded by the loss of specific aquatic habitat types, particularly the unique conditions associated with meltwater from once-permanent hydrological sources like glaciers, snowfields, or subterranean ice (Brown et al. 2007, Milner et al. 2009, Jacobsen et al. 2012, Finn et al. 2013, 2014, Hotaling et al. 2017). Given that many alpine stream communities appear uniquely adapted to cold thermal regimes (but see Hotaling et al. 2019c), they are likely to be highly vulnerable to climate change as meltwater sources are lost (Giersch et al. 2017, Lencioni 2018). However, because alpine streams are heterogeneous with respect to hydrological source, the potential also exists to identify stream types that may be locally buffered from broad-scale climate patterns and therefore could represent climate refugia for alpine stream biota (Morelli et al. 2016).

A major, long-term focus in alpine stream biology has been understanding the links between hydrological sources, the in-stream conditions they promote, and resident biotic communities (Ward 1994, Hotaling et al. 2017). According to primary hydrological source following Ward (1994), 3 types of alpine streams have historically been recognized: surface glacier-fed, snowmelt-fed, and groundwater-fed streams. A fourth, understudied stream type also exists-icy seeps, which are fed by subterranean ice (Hotaling et al. 2017, 2019a). In mountain ecosystems, the most common form of subterranean ice is rock glaciers, masses of debris-covered ice that act as conveyor belts moving fallen rock and other debris slowly downhill (Anderson et al. 2018, Jones et al. 2019). There may be more than 10,000 rock glaciers in the western United States (Johnson 2018) and they are similarly common worldwide (e.g., Lilleøren Etzelmüller 2011, Scotti et al. 2013, Charbonneau and Smith 2018). In contrast, there are $\sim 1250$ surface glaciers and $\sim 3750$ perennial snowfields in the western United States (Fountain et al. 2017). Due to insulating debris cover, rock glaciers are largely decoupled from external conditions (e.g., warm summer air temperatures; Clark et al. 1994, Anderson et al. 2018, Knight et al. 2019), and they should persist on the landscape longer than surface glaciers and snowfields. Icy seeps, the outflow of rock glaciers and similar ice features, may therefore act as climate refugia for coldadapted stream biodiversity (Brighenti et al. 2019a, 2019b, Hotaling et al. 2019a).

As with many mountain ranges worldwide, virtually nothing is known of alpine stream ecology and biodiversity in the Teton Range, a granite-dominated subrange of the Rocky Mountains. Previous studies of montane (2000$3000 \mathrm{~m}$ ), but not alpine, streams revealed considerable macroinvertebrate diversity in the region's higher-elevation streams (Tronstad et al. 2016). Generally speaking, groundwater aquifers appear rare on the Teton Range massif, and thus groundwater-fed streams are also rare (L.M. Tronstad personal observation). Groundwater-fed streams are considered the alpine stream type most resistant to warming because they are not directly influenced by surface ice (e.g., Milner et al. 2009, Jacobsen et al. 2012). With a paucity of groundwater-fed streams in the region, stream biodiversity in the Teton Range may be especially vulnerable to climate change.

In this study, we addressed 2 major objectives. First, we made the first assessment of alpine stream macroinvertebrate diversity in the Teton Range. Second, we explored associations between primary hydrological sources (surface glaciers, snowfields, and subterranean ice) and community structure. Specifically, we asked whether benthic communities associated with icy seeps have substantial taxonomic overlap with communities linked to sources more vulnerable to climate change (e.g., glaciers 
TABLE 1. Key characteristics of our study streams and sites in the Teton Range, Wyoming, USA. Distances to source (D) are cumulative. Elevation and D are measured in meters (m).

\begin{tabular}{llllcrr}
\hline Stream & Code & Site & Type & Latitute, Longitude & Elevation & D \\
\hline Petersen Glacier & PG & Upper & Glacier-fed & $43.782,-110.846$ & 2922 & 51 \\
& & Lower & Glacier-fed & $43.785,-110.841$ & 2900 & 673 \\
Middle Teton & MT & Upper & Glacier-fed & $43.728,-110.795$ & 2955 & 178 \\
& & Lower & Glacier-fed & $43.725,-110.790$ & 2802 & 780 \\
South Cascade Creek & \multirow{2}{*}{ SCC } & Upper & Icy seep & $43.722,-110.838$ & 3152 & 165 \\
& & Lower & Icy seep & $43.729,-110.837$ & 2943 & 1051 \\
Wind Cave & \multirow{2}{*}{ WC } & Upper & Icy seep & $43.666,-110.961$ & 2692 & 29 \\
& & Lower & Icy seep & $43.667,-110.955$ & 2564 & 144 \\
South Fork Teton Creek & \multirow{2}{*}{ SFT } & Upper & Snowmelt & $43.691,-110.843$ & 2987 & 1227 \\
\multirow{2}{*}{ North Fork Teton Creek } & \multirow{2}{*}{ NFT } & Lower & Snowmelt & $43.693,-110.859$ & 2881 & 2757 \\
& & Upper & Snowmelt & $43.777,-110.860$ & 2955 & 9 \\
& & Lower & Snowmelt & $43.775,-110.861$ & 2910 & 393 \\
\hline
\end{tabular}

and snowfields). Our study provides an important first perspective on an urgent need in freshwater ecology (see Brighenti et al. 2019b), testing whether an underappreciated but globally common alpine stream type-icy seeps fed by subterranean ice-may act as key refugia for mountain aquatic biodiversity threatened by global change. Our results also provide new insight into the biodiversity of one of North America's flagship protected areas, Grand Teton National Park, and neighboring wilderness areas.

\section{METHODS}

\section{Study Area}

During the summers of 2015 and 2016 (26 July-10 August), we sampled 6 streams in the Teton Range of Grand Teton National Park and the adjacent Jedediah Smith Wilderness in northwestern Wyoming, USA (Table 1, Fig. 1). Study streams were selected to span the breadth of alpine hydrological sources that we have observed in the Teton Range and included 2 streams fed by surface glaciers ("glacier-fed"), 2 fed by subterranean ice ("icy seep"), and 2 fed by permanent snowpack ("snowmelt-fed"). In 2015, we sampled both upstream (near the source) and downstream sites on each stream (Fig. 1). On average, upper sites were $111 \mathrm{~m}$ higher in elevation and $690 \mathrm{~m}$ in stream distance from lower sites (Table 1). In 2016, we resampled the upper sites with the same methods to assess interannual variability. We focused on upper sites because they were as "true" to primary hydrological source as possible, while lower sites inherently reflected various degrees of mixing among sources. In both years, snow depth in the range was lower than average $(152 \mathrm{~cm}$ in May, 1981-2010), with 2015 and 2016 at $63.3 \%$ and $80 \%$ of normal, respectively (Teton Pass, USDA SNOTEL).

\section{Environmental Data}

At each site, we measured several environmental variables to characterize local habitat and evaluate whether in-stream environmental conditions varied among stream types. We measured water temperature for a full year (2015-2016) with in situ loggers (HOBO Pro v2, Onset Computer Corporation, Bourne, MA) that recorded temperature hourly. We measured specific conductivity (SPC), oxidationreduction potential (ORP), $\mathrm{pH}$, and dissolved oxygen (DO) with a Yellow Springs Instrument (YSI) Professional Plus multiparameter sonde calibrated at the trailhead (SPC, ORP, and $\mathrm{pH}$ ) or at each site (DO). We estimated streambed stability with a modified version of the Pfankuch Index (PI) following Peckarsky et al. (2014). Total suspended sediments (TSS) were calculated by filtering known volumes of streamwater through preweighed filters (PALL Type A/E glass fiber filters) and measuring dry mass to the $10^{-5}$ grams. We used analysis of variance (ANOVA) statistical tests and the R package 'plyr' ( $\mathrm{R}$ Core Development Team 2017, Wickham 2011) to characterize differences in environmental variables (Pfankuch index, specific conductivity, and total suspended solids) among stream types and study sites. When stream type was significant $(\alpha=0.05)$, we used Tukey's HSD to distinguish which stream types differed from one another $(P \leq 0.05)$. Our use of Tukey's HSD tests was highly conservative, given the small sample size of streams in this study. 

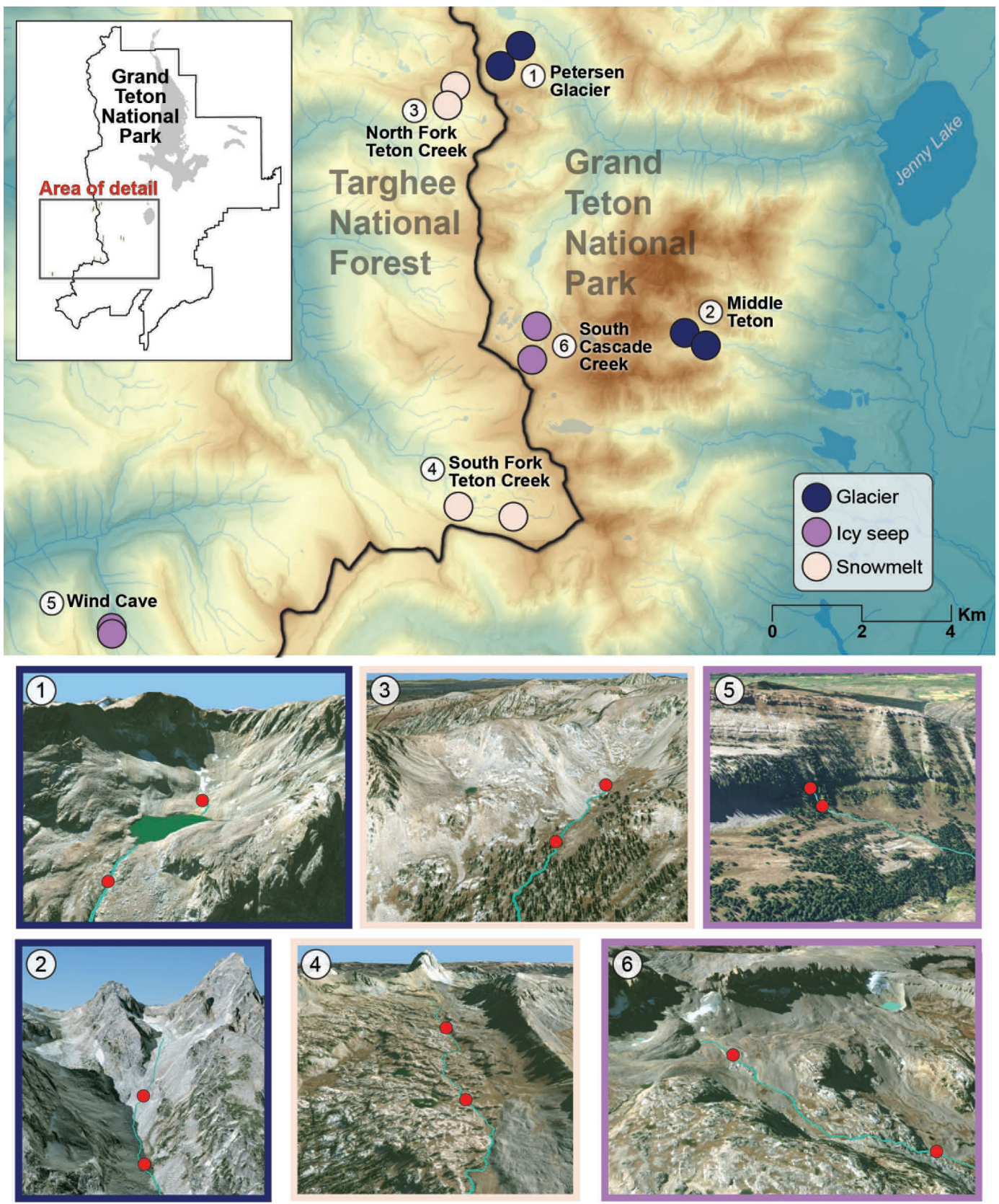

Fig 1. All streams and sites in the Teton Range, Wyoming, USA, included in this study. Upper sites were selected to be as close to the primary hydrological source as possible. Numbers in the top panel correspond to satellite imagery shown in the bottom panels (DigitalGlobe, 15 October 2015), with stream channel (light blue) and sample sites (red dots) marked.

Using the annual temperature data from each stream, we calculated mean temperature for the entire year $\left(\mathrm{T}_{\mathrm{YEAR}}\right)$, mean temperature between the summer solstice (21 June) and autumn equinox (22 September; $\mathrm{T}_{\text {SUMMER }}$ ), and maximum annual temperature range $\left(\mathrm{T}_{\mathrm{RANGE}}\right)$. We also estimated the date when seasonal snow covered $\left(\mathrm{S}_{\mathrm{ON}}\right)$ and uncovered $\left(\mathrm{S}_{\mathrm{OFF}}\right)$ each site by visually inspecting thermographs from our in situ temperature loggers to 
approximate the date when intraday thermal variation ceased and in-stream temperatures became constantly $\sim 0{ }^{\circ} \mathrm{C}\left(\mathrm{S}_{\mathrm{ON}}\right)$ or the opposite occurred $\left(\mathrm{S}_{\mathrm{OFF}}\right)$. An example thermograph indicating $S_{\mathrm{ON}}$ and $S_{\mathrm{OFF}}$ points is provided in Supplementary Material 1. Using $\mathrm{S}_{\mathrm{ON}}$ and $\mathrm{S}_{\text {OFF, }}$, we calculated $\mathrm{S}_{\text {DURATION }}$, the total days a site was snow covered between study years $\left(S_{\text {DURATION }}=S_{\text {ON }}-S_{\text {OFF }}\right)$. Finally, we used principle components analysis (PCA; PC-ORD [McCune and Mefford 2006]) to characterize the upper sites on each stream according to 4 variables (SPC, TSS, PI, $\mathrm{T}_{\text {RANGE}}$ ) which constitute a modified "glaciality index" (Ilg and Castella 2006). Because $\mathrm{T}_{\text {SUMmer }}$ was correlated with $\mathrm{T}_{\text {RANGE}}$, we only included $\mathrm{T}_{\text {RANGE }}$ in the PCA. The glaciality index has been useful in characterizing alpine stream hydrological sources globally (e.g., Finn et al. 2013, Cauvy-Fraunié et al. 2015, Hotaling et al. 2019b).

\section{Macroinvertebrate Sampling}

We quantitatively sampled benthic macroinvertebrates at each site by using a Surber sampler (area: $0.09 \mathrm{~m}^{2}$; mesh size: $243 \mu \mathrm{m}$ ). At each location, a composite sample of 5-10 replicates was collected depending on stream size, apparent biomass, and microhabitat diversity. Samples were elutriated in the field to reduce the amount of inorganic substrate and then stored in Whirl-Pak ${ }^{\circledR}$ bags with $\sim 80 \%$ ethanol. In the laboratory, invertebrate samples were divided into large $(>2 \mathrm{~mm}$ mesh) and small (between $250 \mu \mathrm{m}$ and $2 \mathrm{~mm}$ ) fractions. For the large fraction, all invertebrates were identified. The small fraction was subsampled using the record player method when invertebrates were numerous (Waters 1969). Specimens were sorted, identified to the lowest taxonomic level possible by using keys in Merritt et al. (2008) and Thorp and Covich (2010), and counted under a dissecting microscope. Insects were typically identified to genus when mature specimens were present, except Chironomidae, which were classified as either Tanypodinae or non-Tanypodinae. We estimated invertebrate density by summing the total number of individuals for a given site and dividing by the area of streambed sampled. We calculated biomass by measuring the length of the first 20 individuals of each taxon and then using length-mass regressions to estimate individual biomass (Benke et al. 1999).
We multiplied the mean individual biomass for each taxon by the total number collected to estimate total biomass.

\section{Biological Data Analysis}

We used ANOVAs and Tukey's HSD tests performed on data summarized with 'plyr' (Wickham 2011, R Core Development Team 2017) to characterize differences in invertebrate density, biomass, and richness among stream types and study sites. To assess the relationship between taxonomic richness or biomass with stream characteristics of interest, namely snow cover $\left(S_{\text {DURATION }}\right)$, temperature ( $\left.\mathrm{T}_{\text {SUMmeR }}\right)$, and stability (Pfankuch Index), we performed both Pearson's and Spearman's rank-order correlations using the $\mathrm{R}$ package 'Hmisc' (Harrell and Dupont 2013). For correlation analyses, we focused exclusively on upper sites and averaged taxonomic richness and biomass between 2015 and 2016 .

We evaluated differences in community structure across streams, sites, and study years using nonmetric multidimensional scaling (NMS) with PC-ORD (McCune and Mefford 2006). We $\log _{10}(n+1)$-transformed density data for all taxa, removed rare taxa (either those private to a single site in the matrix and/or representing $<1 \%$ of the total abundance), and used Sørensen's dissimilarities to create distance matrices. We ran NMS analyses independently on 2 data matrices: one including each of the upper and lower sites collected in 2015 only ( $n=12$ sites), and the other including only the upper sites (sampled in both 2015 and 2016; $n=12$ sites). Dimensionality of the final solutions was chosen as the number of axes that produced the lowest stress following 200 iterations. Following NMS, we applied multiresponse permutation procedures (MRPP) in PC-ORD to assess whether there were differences in community structure and/or mean community distance within the following groups: upstream versus downstream sites (2015 only) and among stream types for upper sites only (2015 and 2016). We then used Indicator Species Analysis (ISA) in PC-ORD to assess whether any specific taxa in the input matrices were indicative of (a) upper or lower sites or (b) a specific stream type. In ISA, the indicator value (IV) for a taxon is the test statistic. The maximum IV is 100 , which indicates that a taxon is found in one group alone and is absent from other 


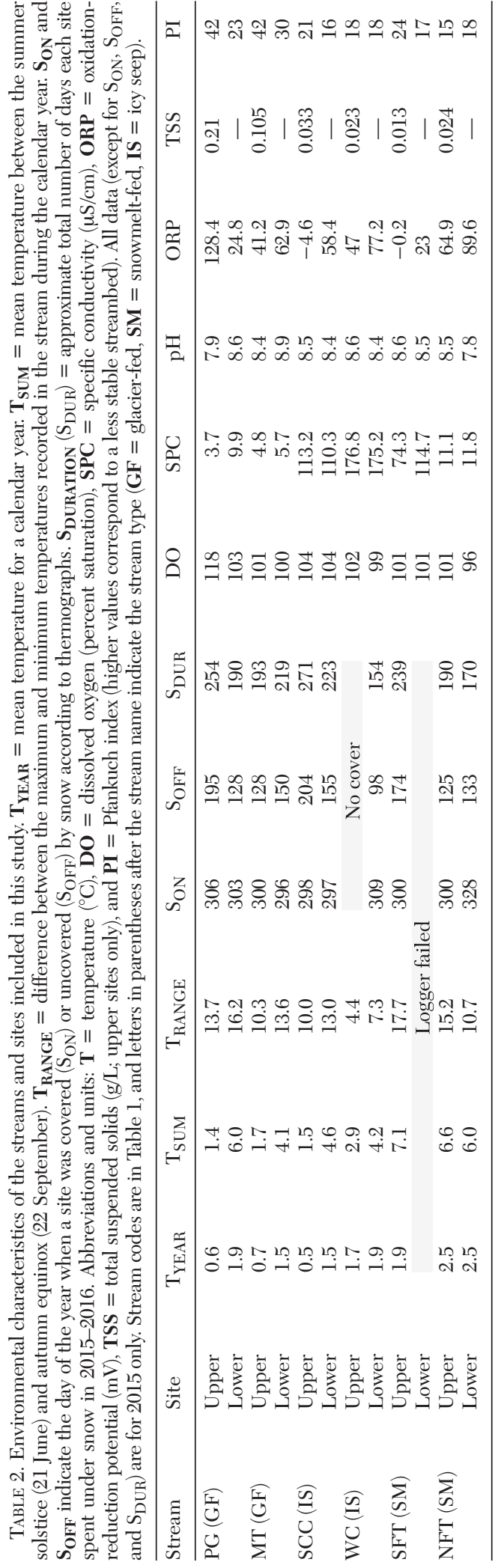

groups. We tested for significance of all IVs using Monte Carlo randomizations with 15,000 permutations of the data for each of the 2 tests (a and $b$ above).

\section{RESULTS}

\section{Environmental Variation}

Our upper sites clearly separated into 3 groups according to the glaciality index: glacier-fed streams, snowmelt-fed streams, and icy seeps (Table 2, Fig. 2). Glacier-fed streams had less stable streambeds than both icy seeps and snowmelt-fed streams $(F=19.9, \mathrm{df}=2, P=$ 0.0001; Tukey's HSD: $P<0.001$; Table 2). Annual temperature range $\left(\mathrm{T}_{\mathrm{RANGE}}\right)$ was highest in snowmelt-fed streams and lowest in icy seeps. Specific conductivity was highest in icy seeps $(\mathrm{SPC}>100 \mu \mathrm{S} / \mathrm{cm}$ at upper sites; $F=$ 30.6, $\mathrm{df}=2, P<0.001$; Tukey's HSD: $P<$ $0.001)$ and lowest in glacier-fed streams (Table 2). More suspended solids (TSS) were present in glacier-fed streams $(\bar{x}=0.157 \mathrm{~g} / \mathrm{L})$ compared to snowmelt-fed streams $(F=3.6$, $\mathrm{df}=2, P=0.44$; Tukey's HSD: $P=0.039$; Table 2). Summer temperatures ( $\mathrm{T}_{\text {SUMmER }}$ ) were lowest in glacier-fed streams $(\bar{x}=$ $\left.1.6^{\circ} \mathrm{C}\right)$ and icy seeps $\left(\bar{x}=2.2^{\circ} \mathrm{C}\right)$, and higher in snowmelt-fed streams $\left(\bar{x}=6.9^{\circ} \mathrm{C}\right.$; Table 2$)$. Upper sites were on average $1.2^{\circ} \mathrm{C}$ colder in the summer and had less stable streambeds than lower sites (mean PI, upper $=27$; mean PI, lower $=20.33$; Table 1 ). Other environmental variables (i.e., DO, pH, ORP, days under snow) did not vary among stream types or between upper and lower sites (Table 2).

\section{Biological Variation}

We collected 35 total invertebrate taxa, of which 28 were insects (Supplementary Material 2). Insects composed $95 \%$ of the total mean densities and $92 \%$ of the total biomass. While invertebrate densities varied across stream types, biomass and richness were highest in snowmelt-fed streams (Fig. 3a, Supplementary Material 3). At upper sites, total macroinvertebrate density did not differ among stream types $(F=1.3$, df $=2, P=0.31$; Fig. 3a), but biomass was approximately $7 \times$ higher in snowmelt-fed streams compared to glacier-fed streams and icy seeps $(F=7.1, \mathrm{df}=2, P<$ 0.009; Tukey's HSD: $P \leq 0.02$; Fig. 3b). Additionally, invertebrate richness was approximately $2 \times$ higher in snowmelt-fed streams 


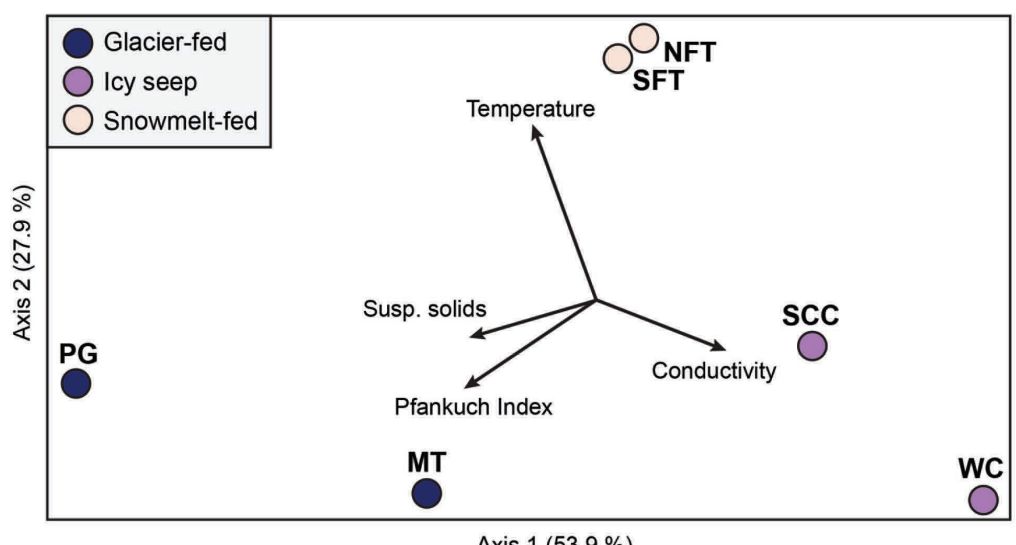

Axis $1(53.9 \%)$

Fig. 2. Principal components analysis (PCA) results showing environmental variation among the upper sites according to the 4 variables of the glaciality index (specific conductivity, streambed stability [Pfankuch index], suspended solids, and temperature $\left.\left[\mathrm{T}_{\text {RANGE}}\right]\right)$. MT $=$ Middle Teton, NFT $=$ North Fork Teton Creek, PG $=$ Petersen Glacier, $\mathrm{SCC}=$ South Cascade Creek, SFT $=$ South Fork Teton Creek, and WC $=$ Wind Cave.
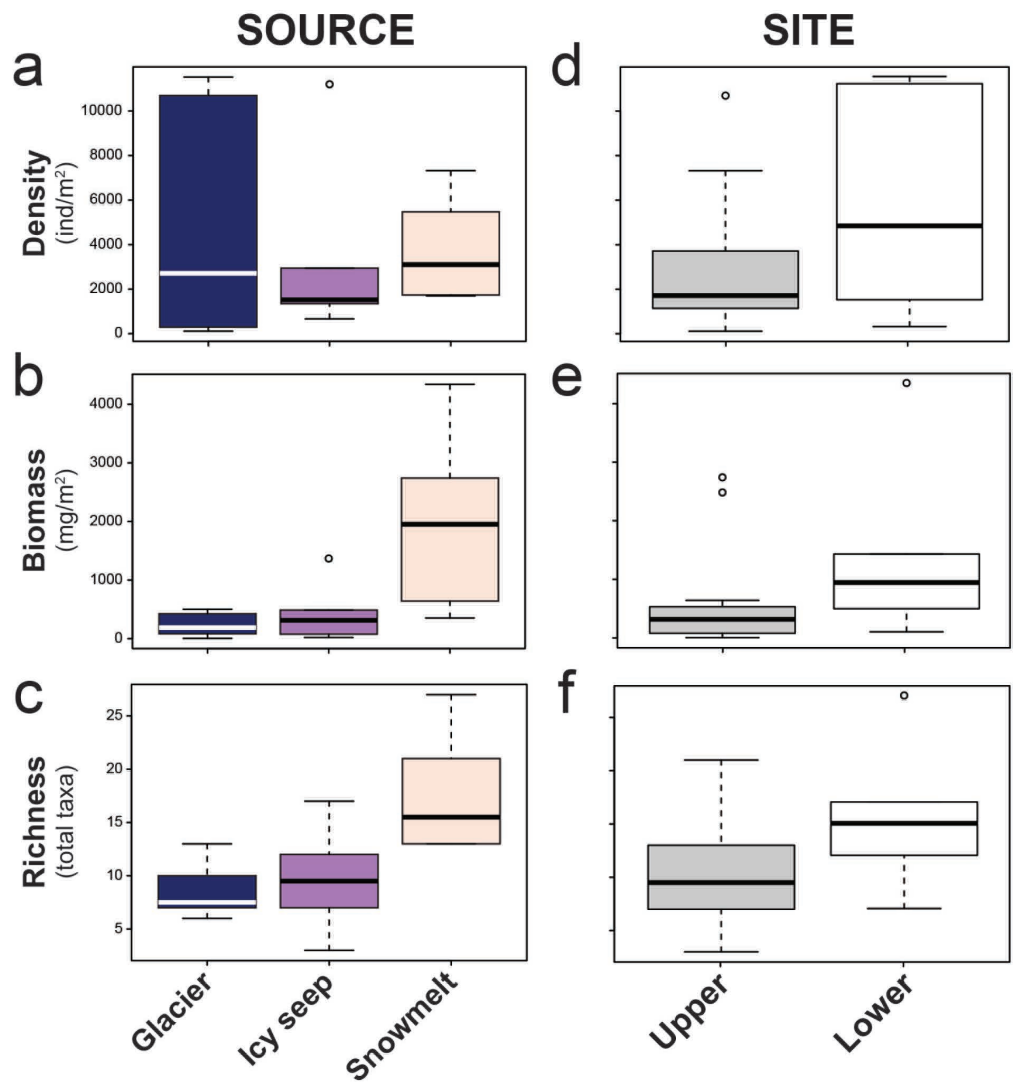

Fig. 3. Macroinvertebrate density, biomass, and richness among sites categorized by hydrologic source (a-c; upper sites only in 2015 and 2016 ) or site $(\boldsymbol{d}-\boldsymbol{f} ; 2015$ and 2106 data for upper sites, 2015 data only for lower sites). Bold lines are median values; lower and upper box limits indicate the 25 th and 75 th percentiles, respectively; and whiskers represent the lower and upper limits of the data (excluding outliers which are shown as circles). 

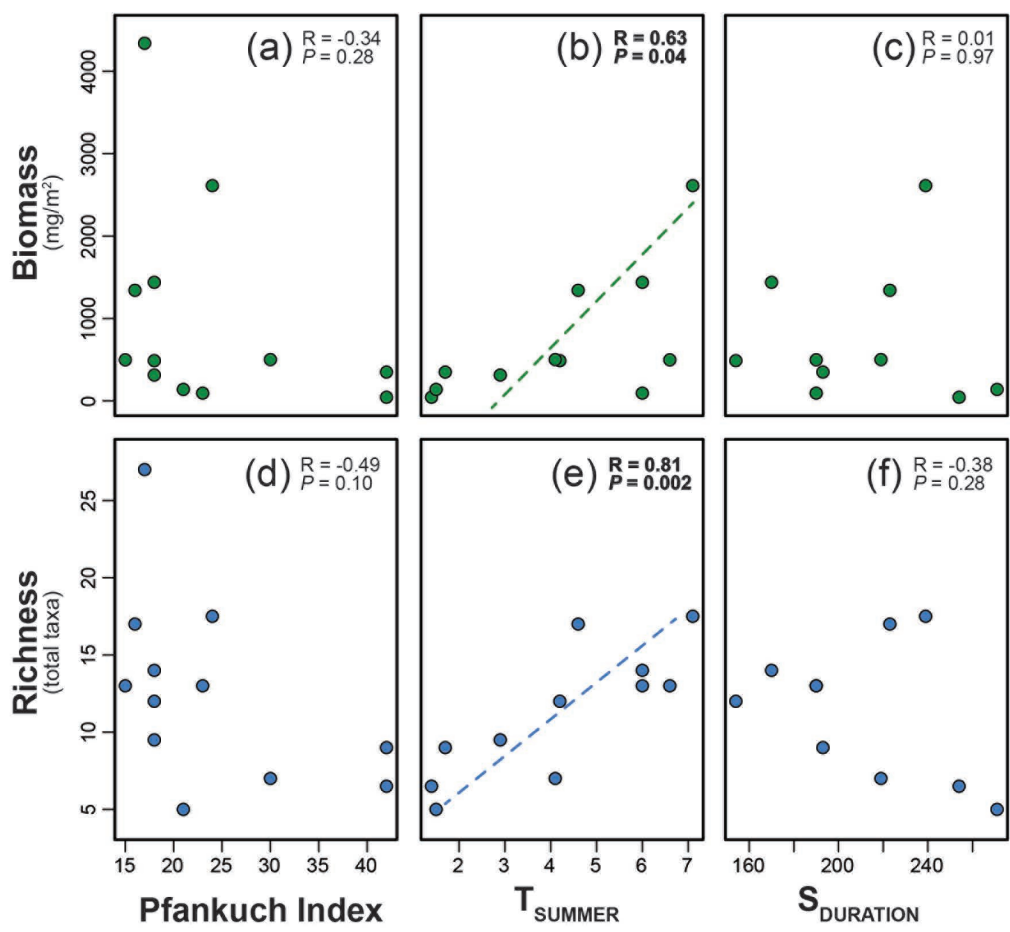

Fig. 4. Bivariate plots of biomass $(\boldsymbol{a}-\boldsymbol{c})$ and richness $(\boldsymbol{d}-\boldsymbol{f})$ versus the Pfankuch index (a measure of streambed stability; higher values indicate less stability), $\mathrm{T}_{\text {SUMmeR }}$ (mean stream temperature between the summer and autumn solstices), and $S_{\text {DURATION }}$ (the approximate number of days each stream was snow covered in 2015-2016). Significant Pearson correlations $(P<0.05)$ are in bold with trendlines shown. The number of data points varies across plots due to a lack of snow cover at upper Wind Cave during the study period and a failed temperature logger at lower South Fork Teton Creek (see Table 2).

than in glacier-fed streams and icy seeps $(F=$ 10.4, df $=2, P<0.002$; Tukey's HSD: $P<$ 0.008 ; Fig. 3c). We observed generally higher and more variable invertebrate densities $(F=$ 2.7 , $\mathrm{df}=1, P=0.13$; Fig. $3 \mathrm{~d}$ ) and higher biomass $(F=2.6$, df $=1, P=0.13$; Fig. $3 \mathrm{e})$ at lower sites. We also observed about $50 \%$ more taxa at lower sites $(F=8.5, \mathrm{df}=1, P=0.012$; Fig. 3f). Only $\mathrm{T}_{\text {SUMmer }}$ was significantly correlated with richness or biomass (Richness: Pearson $r=0.81, P=0.002$; Biomass: Pearson $r=0.63, P=0.038$; Fig. 4). Spearman's rankorder correlations of the same relationships exhibited similar patterns, again with only $\mathrm{T}_{\text {SUMMER }}$ exhibiting significant correlations with richness (Spearman's $r=0.89, P=0.003$ ) and biomass (Spearman's $r=0.67, P=0.023$ ).

The most common invertebrates in highelevation Teton streams were non-Tanypodinae midges $(78.6 \%$ of all specimens sampled; $>100$ individuals $/ \mathrm{m}^{2}$ at all sites; Supplementary Material 2) followed by Neothremma (caddisflies), nematodes, and Epeorus (mayflies). Additionally, $45.7 \%$ of taxa had densities $>10$ individuals $/ \mathrm{m}^{2}$ among sites. Three taxa (Perlodidae, Zapada, and Empididae) were present at $67 \%$ of sites, and 12 taxa (34.3\%), including Lednia tetonica, were found at only a single site (Supplementary Material 2). Overall, we observed more stoneflies (6 taxa) than caddisflies (5 taxa) and mayflies (4 taxa; Supplementary Material 2). Only 2 taxa (midges and Collembola) were collected at upper sites of both glacier-fed streams (Supplementary Material 2). Two taxa were also present at both upper icy seep sites (midges and the stonefly genus Zapada), and 4 taxa were present in upper snowmelt-fed sites (midges, stoneflies [Perlodidae], caddisflies [Allomyia], and flatworms [Turbellaria]). Of those, only Turbellaria were present at consistently high numbers (i.e., $>20$ individuals $/ \mathrm{m}^{2}$ per site; Supplementary Material 2). No taxon exclusively occurred in one stream type, and 3 occurred in upper 


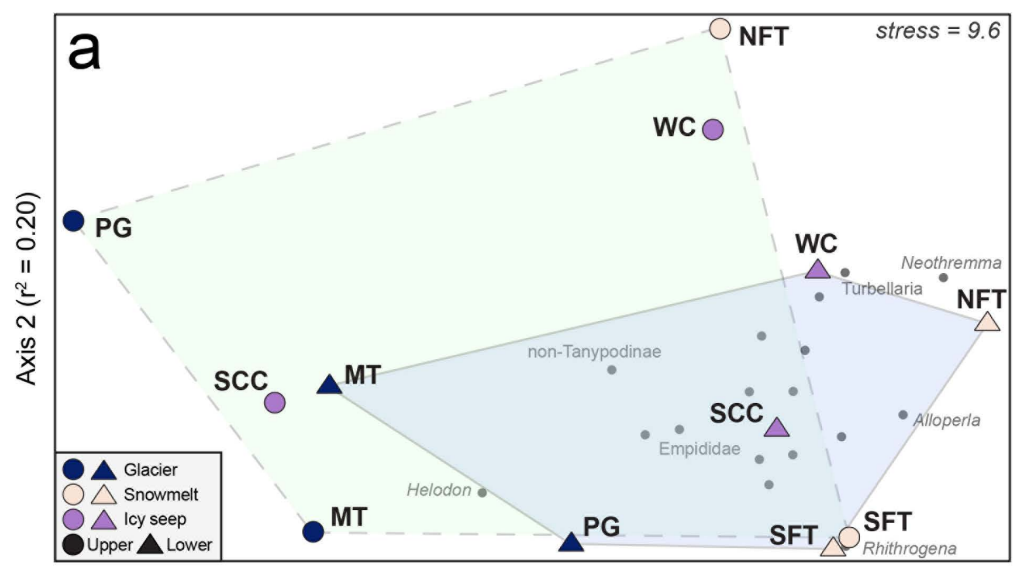

Axis $1\left(r^{2}=0.68\right)$

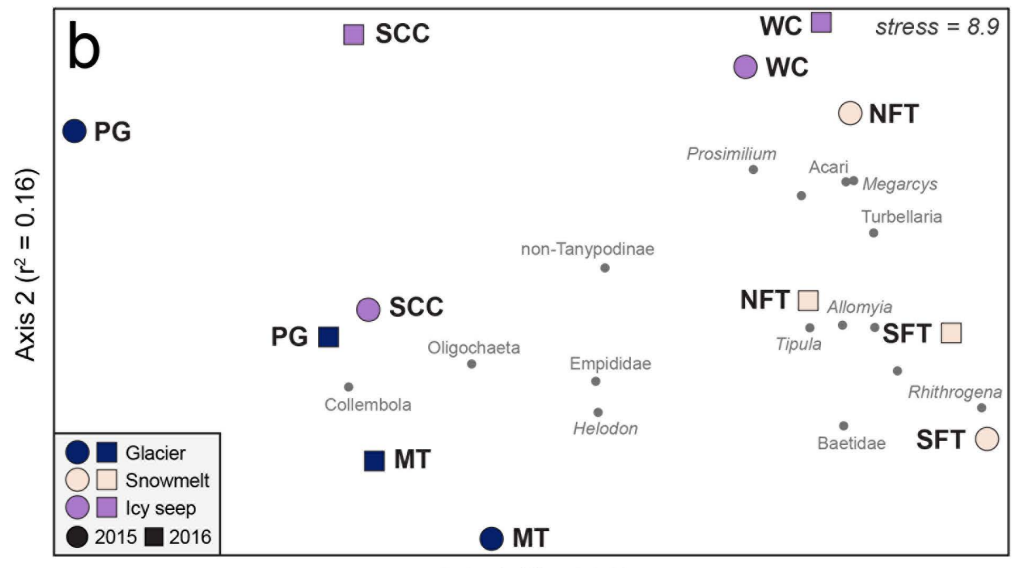

Axis $1\left(r^{2}=0.70\right)$

Fig. 5. Nonmetric multidimensional scaling (NMS) plots of macroinvertebrate communities. Panel $\boldsymbol{a}$, Upper (circles) versus lower (triangles) sites in 2015. Panel $b$, Upper sites only between 2015 (circles) and 2016 (squares). Colored polygons in panel $a$ reflect the breadth of NMS space occupied by upper (dashed lines, green fill) and lower (solid lines, blue fill) sites. MT $=$ Middle Teton, NFT $=$ North Fork Teton Creek, PG = Petersen Glacier, SCC $=$ South Cascade Creek, SFT $=$ South Fork Teton Creek, and WC $=$ Wind Cave.

sites of all stream types (midges, Allomyia caddisflies, and Helodon black flies; Supplementary Material 2).

The most stable NMS solution comparing community structure between upper and lower sites was 3-dimensional (stress $=9.6$ ), with the first 2 axes explaining $88 \%$ of the total variation. Communities from the 6 lower sites overlapped substantially in ordination space with those from the 6 upper sites (MRPP $A=$ $0.013, P=0.27)$. However, the mean pairwise community distance was greater among upper versus lower sites (0.58 vs. 0.47$)$, a trend that is apparent in the NMS biplot (Fig. 5a). Indicator species analyses revealed no taxon with
IV scores approaching the maximum of 100 (Supplementary Materials 4 and 5), an expected result when 2 assemblages substantially overlap in ordination space. Mean IV across all taxa was 44.3, and Empididae had the maximum IV (78.9; $P=0.025)$ of lower sites.

The NMS analysis that included upper sites only (2015 and 2016) converged on a 2-dimensional solution as the most stable result (stress $=8.9)$. The 2 axes explained $86 \%$ of the variation, with axis-1 explaining $70 \%$ alone. In general, communities occupying glacier-fed streams had the lowest axis- 1 values, communities in snowmelt-fed streams had the highest axis-1 values, and icy seep communities had 
intermediate axis-1 values (Fig. 5b). MRPP results suggested that communities occupying these 3 stream types were significantly different from one another $(A=0.19, P=0.006)$. Pairwise differences were strong between glacier-fed and snowmelt-fed communities ( $A=0.21, P=0.005)$ and were weaker but significant for the 2 pairs that included icy seep communities (icy seep vs. glacier-fed: $A=0.11$, $P=0.05$; icy seep vs. snowmelt-fed: $A=0.12$, $P=0.03$ ). Indicator species analysis (Supplementary Material 5) revealed IV scores $>80$ for 3 taxa, of which one was indicative of glacier-fed streams (Collembola: IV $=85.0$, $P=0.02$ ) and 2 were indicative of snowmelt streams (Tipulidae: IV $=82.1, P=0.004$; Allomyia: IV $=81.5, P=0.004)$. Turbellaria were also weakly indicative of snowmelt streams $(\mathrm{IV}=72.5, P=0.011)$.

\section{Discussion}

As climate change proceeds and mountain glaciers recede, there is a need to develop a clearer understanding of how patterns of extant biodiversity and habitat heterogeneity are linked in high-elevation ecosystems. In this study, we provide the first description of macroinvertebrate diversity in the high Teton Range, Wyoming, where 3 major alpine stream types exist: glacier-fed streams, snowmelt-fed streams, and icy seeps. To the best of our knowledge, no streams fed by groundwater aquifers have been documented in the alpine zone of the granitic Teton Range. From a global perspective, icy seeps, which are fed by subterranean ice (primarily rock glaciers) rather than aquifers of liquid water, are of particular interest because they are likely to persist on the landscape longer than surface ice features (Hotaling et al. 2019a). For the Teton Range, a scarcity of high-elevation, groundwater-fed streams suggests that biodiversity in the region may be even more reliant on meltwater than biodiversity in similar mountain regions (e.g., European ranges [Brown et al. 2007]; tropical Andes [Finn et al. 2016]; Glacier National Park [Giersch et al. 2017]). Thus, icy seep-associated climate refugia may be particularly important to Teton alpine stream biodiversity as climate change proceeds. In the streams sampled for this study, glacierand snowmelt-fed streams exhibited significantly different invertebrate communities; however, icy seeps were intermediate between the two in terms of community structure and invertebrate density, biomass, and richness. These results suggest that icy seep communities share some characteristics with both glacier- and snowmelt-fed streams and have the potential to act as climate refugia for at least a subset of the unique communities present in each of the more vulnerable stream types. Thus, the potential for icy seeps and ice-influenced terrestrial refugia (Millar et al. 2015) to buffer climate-induced biodiversity loss has profound, global implications.

The recession of meltwater sources is predicted to strongly affect downstream invertebrate communities (Jacobsen et al. 2012). In the near term, rising in-stream temperatures are expected as ice melt comprises ever smaller proportions of stream flow. In alpine streams worldwide, warmer conditions have been correlated with increased species richness for microbial diversity (e.g., Wilhelm et al. 2013, Hotaling et al. 2019a), diatoms (Fell et al. 2018), and macroinvertebrates (Finn and Poff 2005, Jacobsen et al. 2012). Our study adds another line of evidence to this global pattern because we detected a positive correlation between species richness and mean summer temperature $\left(\mathrm{T}_{\text {SUMMER }}\right)$. We also observed greater richness at lower $(\bar{x}=15$ taxa) versus upper $(\bar{x}=10$ taxa) sites, which aligns with, and extends, the conclusions of Tronstad et al. (2016), the only other study to investigate longitudinal patterns of macroinvertebrate richness in montane streams of the Teton Range. Indeed, we observed far fewer taxa at our highest-elevation sites (10 taxa at $\sim 3150 \mathrm{~m}$ ) versus the highest-elevation sites included in Tronstad et al. (2016) (26 taxa at $\sim 2700 \mathrm{~m}$ ).

Although local (alpha) diversity will likely increase with warming water temperatures, among-stream (beta) diversity may decrease as more diverse, generalist communities shift upstream and specialized cold-adapted taxa are lost, effectively homogenizing biological diversity at the regional scale (Jacobsen et al. 2012, Wilhelm et al. 2013, Hotaling et al. 2017). In the Teton Range, we observed greater beta diversity at upper versus lower sites, and ISA revealed indicator taxa for snowmelt and glacier-fed streams, but not for icy seeps. Collectively, these patterns suggest that in the Teton Range, like elsewhere in the world, 
heterogeneous hydrological sources bolster regional-scale alpine stream biodiversity. Icy seep communities also appeared to bridge the taxonomic gap between glacier- and snowmelt-fed streams, and this pattern remained stable between years (Fig. 5B). While clear patterns of community dissimilarity existed among our sites, ascribing a specific driver to these differences is difficult. Many factors likely shape community structure in headwater streams (and our estimation of it), including the primary source and its associated environmental regime, geographic location, and both the method and timing of sampling (e.g., a site recently uncovered from seasonal snowpack is likely to have a distinct community compared to a site that melted out much earlier).

Our study represents the first perspective of macroinvertebrate biodiversity in the highest-elevation streams of the Teton Range. As such, there are many areas where future study will expand, and refine, our conclusions. First, we did not have the resources to identify midges (family Chironomidae) to lower taxonomic resolution. Midges are diverse in alpine streams around the world (e.g., Montagna et al. 2016) and are typically the most common taxon (a pattern we also observed). Thus, the limited taxonomic resolution of midges in our study may have influenced our conclusions. For instance, Finn and Poff (2011) found 22 midge species in snowmelt-fed alpine streams of the Colorado Rockies. Given our focus on 3 stream types, we might expect even greater midge species diversity in the Teton Range. Second, our focus on a limited number of sites, lack of within-year temporal sampling, and use of a single sampling method/microhabitat (Surber samples from riffle habitats) rather than many approaches/habitats (e.g., Ghani et al. 2016, Tronstad and Hotaling 2017), limits our ability to confidently describe the full invertebrate community at a given site. We hope to fill these gaps in the future.

Ultimately, the degree to which alpine streams will be affected by climate change in terms of flow magnitude and persistence remains largely unknown. In general, studies of alpine stream ecology operate under the assumption that perennial flow will continue in the decades to come (e.g., Jacobsen et al. 2012), but this may not be the case (e.g., Haldorsen and Heim 1999, Herbst et al. 2019,
Siebers et al. 2019). Thus, the biological ramifications of declining meltwater sources in places like the Teton Range, where groundwater aquifer-fed streams are scarce, may be even more profound than in ranges with a more equitable distribution of alpine stream sources (e.g., Glacier National Park [Giersch et al. 2017]). Indeed, if alpine streams supported by surface glaciers and permanent snowfields transition to intermittency or dry completely, the future of biodiversity in these ecosystems may depend almost exclusively on icy seeps. Our study, paired with the broader glaciological literature, suggests that there is room for optimism. Icy seeps have the potential to span a wide beta-diversity profile, perhaps bridging the taxonomic gap between glacier- and snowmelt-fed communities (e.g., as observed for microbial diversity [Hotaling et al. 2019a]). Moreover, rock glaciers and other subterranean ice forms (e.g., periglacial taluses [Millar et al. 2013]) are common in alpine regions worldwide and are likely the ice form most resistant to future warming. Clearly, research focused on subterranean ice sources and associated icy seeps, and specifically the biological communities and hydrological flows they support, represent a pressing need in alpine stream biology. We suggest that future studies incorporate temporal monitoring of multiple alpine stream types, including icy seeps, to separate year-to-year variation from true temporal signals. Long-term data will also allow for explicit tests of how biodiversity and habitat characteristics may be altered among alpine stream types as climate change proceeds.

\section{Supplementary Material}

Five online-only supplementary files accompany this article (https://scholarsarchive.byu .edu/wnan/vol80/iss3/11).

Supplementary Material 1. An example thermograph of a stream (Middle Teton, Upper) included in this study, showing the dates when the stream became covered $\left(\mathrm{S}_{\mathrm{ON}}\right)$ and uncovered $\left(\mathrm{S}_{\mathrm{OFF}}\right)$ by snow.

Supplementary Material 2. All taxa observed across study sites in 2015 when both upper and lower sites were sampled. Densities for each taxon are given.

Supplementary Material 3. Macroinvertebrate density, biomass, and richness for each combination of site and year included in this study. 
Supplementary Material 4. Results of an indicator species analysis assessing the degree to which an individual taxon is associated with a given site (upper or lower; 2015 data only).

Supplementary Material 5. Results of an indicator species analysis assessing the degree to which an individual taxon is associated with a given stream type (glacier-fed, snowmelt-fed, or icy seep; 2015 and 2016 data).

\section{ACKNOWLEDGMENTS}

Financial support was provided by the University of Wyoming-National Park Service Research Station and the Teton Conservation District. We thank Lydia Zeglin for assistance in the field and Hanna Foster, Logan Fox, Alexis Lester, Jackson Marr, Jake Ruthven, Joe Wannemuehler, and Kara Wise for their help with sorting invertebrate samples. Matthew Green provided helpful comments on the manuscript. Any use of trade, firm, or product names is for descriptive purposes only and does not imply endorsement by the U.S. Government.

\section{Literature Cited}

Anderson, R.S., L.S. Anderson, W.H. Armstrong, M.W. Rossi, AND S.E. Crump. 2018. Glaciation of alpine valleys: the glacier-debris-covered glacier-rock glacier continuum. Geomorphology 311:127-142.

Benke, A.C., A.D. Huryn, L.A. Smock, And J.B. WaLLACE. 1999. Length-mass relationships for freshwater macroinvertebrates in North America with particular reference to the southeastern United States. Journal of the North American Benthological Society 18:308-343.

Bradley, R.S., M. Vuille, H.F. Diaz, and W. Vergara. 2006. Threats to water supplies in the tropical Andes. Science 312:1755-1756.

Brighenti, S., M. Tolotti, M.C. Bruno, M. Engel, G. Wharton, L. Cerasino, V. Mair, and W. Bertoldi. 2019a. After the peak water: the increasing influence of rock glaciers on alpine river systems. Hydrological Processes 33:2804-2823.

Brighenti, S., M. Tolotti, M.C. Bruno, G. Wharton, M.T. Pusch, AND W. Bertoldi. 2019b. Ecosystem shifts in Alpine streams under glacier retreat and rock glacier thaw: a review. Science of the Total Environment 675:542-559.

Brown, L.E., D.M. Hannah, and A.M. Milner. 2007. Vulnerability of alpine stream biodiversity to shrinking glaciers and snowpacks. Global Change Biology 13: 958-966.

Cauvy-Fraunié, S., R. Espinosa, P. Andino, D. Jacobsen, AND O. DANGLES. 2015. Invertebrate metacommunity structure and dynamics in an Andean glacial stream network facing climate change. PLOS ONE 10: $\mathrm{e} 0136793$.

Charbonneau, A.A., AND D.J. Smith. 2018. An inventory of rock glaciers in the central British Columbia
Coast Mountains, Canada, from high resolution Google Earth imagery. Arctic, Antarctic, and Alpine Research 50:e1489026.

Clark, D.H., M.M. Clark, and A.R. Gillessie. 1994. Debris-covered glaciers in the Sierra Nevada, California, and their implications for snowline reconstructions. Quaternary Research 41:139-153.

Fell, S.C., J.L. Carrivick, M.G. Kelly, L. FÜreder, and L.E. Brown. 2018. Declining glacier cover threatens the biodiversity of alpine river diatom assemblages. Global Change Biology 24(12):5828-5840.

Finn, D.S., A.C. Encalada, and H. Hampel. 2016. Genetic isolation among mountains but not between stream types in a tropical high-altitude mayfly. Freshwater Biology 61:702-714.

Finn, D.S., K. Khamis, And A.M. Milner. 2013. Loss of small glaciers will diminish beta diversity in Pyrenean streams at two levels of biological organization. Global Ecology and Biogeography 22:40-51.

FINN, D.S., AND N.L. POFF. 2005. Variability and convergence in benthic communities along the longitudinal gradients of four physically similar Rocky Mountain streams. Freshwater Biology 50:243-261.

Finn, D.S., AND N.L. Poff. 2011. Examining spatial concordance of genetic and species diversity patterns to evaluate the role of dispersal limitation in structuring headwater metacommunities. Journal of the North American Benthological Society 30:273-283.

Finn, D.S., C. Zamora-Muñoz, C. Múrria, M. SáinzBariáin, and J. Alba-Tercedor. 2014. Evidence from recently deglaciated mountain ranges that Baetis alpinus (Ephemeroptera) could lose significant genetic diversity as alpine glaciers disappear. Freshwater Science 33:207-216.

Fountain, A.G., B. Glenn, and H.J. Basagic. 2017. The geography of glaciers and perennial snowfields in the American West. Arctic, Antarctic, and Alpine Research 49:391-410.

Ghani, W.M., C.S. RaWi, S.A. Hamid, and S.A. Al-Shami. 2016. Efficiency of different sampling tools for aquatic macroinvertebrate collections in Malaysian streams. Tropical Life Sciences Research 27:115-133.

Giersch, J.J., S. Hotaling, R.P. Kovach, L.A. Jones, and C.C. MuHLFELD. 2017. Climate-induced glacier and snow loss imperils alpine stream insects. Global Change Biology 23:2577-2589.

Haldorsen, S., and M. Heim. 1999. An Arctic groundwater system and its dependence upon climatic change: an example from Svalbard. Permafrost and Periglacial Processes 10:137-149.

Hall, M.H.P., AND D.B. Fagre. 2003. Modeled climateinduced glacier change in Glacier National Park, 1850-2100. BioScience 53:131-140.

Hansen, J., L. Nazarenko, R. Ruedy, M. Sato, J. Willis, A. Del Genio, D. Koch, A. Lacis, K. Lo, S. Menon, ET AL. 2005. Earth's energy imbalance: confirmation and implications. Science 308:1431-1435.

Harrell, FE., and C. Dupont. 2013. Hmisc: Harrell miscellaneous. $\mathrm{R}$ package version 3.12-2 [computer software]. https://cran.R-project.Org/web/packages/Hmisc

Herbst, D.B., S.D. Cooper, R.B. Medhurst, S.W. Wiseman, AND C.T. HunsaKer. 2019. Drought ecohydrology alters the structure and function of benthic invertebrate communities in mountain streams. Freshwater Biology 64:886-902.

Hotaling, S., D.S. Finn, J.J. Giersch, D.W. Weisrock, AND D. JACOBSEn. 2017. Climate change and alpine 
stream biology: progress, challenges, and opportunities for the future. Biological Reviews 92:2024-2045.

Hotaling, S., M. Foley, L. Zeglin, D. Finn, L. Tronstad, J. Giersch, C. Muhlfeld, and D.W. WeisROCK. 2019a. Microbial assemblages reflect environmental heterogeneity in alpine streams. Global Change Biology 25(8):2576-2590.

Hotaling, S., J.J. Giersch, D.S. Finn, L.M. Tronstad, S. Jordan, L.E. Serpa, R.G. Call, C.C. Muhlfeld, AND D.W. WeIsrock. 2019b. Congruent population genetic structure but differing depths of divergence for three alpine stoneflies with similar ecology and geographic distributions. Freshwater Biology 64: 335-347.

Hotaling, S., A.A. Shah, K.L. McGowan, L.M. TronStad, J.J. Giersch, D.S. Finn, H.A. Woods, M.E. Dillon, And J.L. Kelley. 2019c. Mountain stoneflies may tolerate warming streams: evidence from organismal physiology and gene expression. bioRxiv 2019.12.16.878926.

Ilg, C., AND E. CASTELla. 2006. Patterns of macroinvertebrate traits along three glacial stream continuums. Freshwater Biology 51:840-853.

Jacobsen, D., A.M. Milner, L.E. Brown, and O. DanGLES. 2012. Biodiversity under threat in glacier-fed river systems. Nature Climate Change 2:361-364.

Johnson, G.F. 2018. Rock glaciers of the contiguous United States: spatial distribution, cryospheric context, and riparian vegetation. Doctoral dissertation, Portland State University, Portland, OR. 147 pp.

Jones, D.B., S. Harrison, K. Anderson, and W.B. WHALLEY. 2019. Rock glaciers and mountain hydrology: a review. Earth-Science Reviews 193:66-90.

Knight, J., S. Harrison, and D.B. Jones. 2019. Rock glaciers and the geomorphological evolution of deglacierizing mountains. Geomorphology 324:14-24.

LENCIONI, V. 2018. Glacial influence and stream macroinvertebrate biodiversity under climate change: lessons from the Southern Alps. Science of the Total Environment 622-623:563-575.

Lilleøren, K.S., AND B. Etzelmüller. 2011. A regional inventory of rock glaciers and ice cored moraines in Norway. Geografiska Annaler: Series A, Physical Geography 93:175-191.

McCune, B., AND M. Mefford. 2006. PC-ORD 5.0. Multivariate analysis of ecological data. Gleneden Beach, OR.

Merritt, R.W., K.W. Cummins, And M.B. Berg. 2008. An introduction to the aquatic insects of North America, 4th edition. Kendall/Hunt Publishing Company, Dubuque, IA.

Millar, C.I., R.D. Westfall, and D.L. Delany. 2013 Thermal and hydrologic attributes of rock glaciers and periglacial talus landforms: Sierra Nevada, California, USA. Quaternary International 310:169-180.

Millar, C.I., R.D. Westfall, A. Evenden, J.G. HolmQuist, J. Schmidt-Gengenbach, R.S. Franklin, J. Nachlinger, and D.L. Delany. 2015. Potential climatic refugia in semi-arid, temperate mountains: plant and arthropod assemblages associated with rock glaciers, talus slopes, and their forefield wetlands, Sierra Nevada, California, USA. Quaternary International 387:106-121.
Milner, A.M., L.E. Brown, and D.M. Hannah. 2009. Hydroecological response of river systems to shrinking glaciers. Hydrological Processes 23:62-77.

Montagna, M., V. Mereghetti, V. Lencioni, and B. Rossaro. 2016. Integrated taxonomy and DNA barcoding of alpine midges (Diptera: Chironomidae). PLOS ONE 11(7):e0159124.

Morelli, T.L., C. Daly, S.Z. Dobrowski, D.M. Dulen, J.L. Ebersole, S.T. Jackson, J.D. Lundquist, C.I. Millar, S.P. Maher, W.B. Monahan, et al. 2016. Managing climate change refugia for climate adaptation. PLOS ONE 12(1):e0169725.

Peckarsky, B.L., A.R. McIntosh, S.C. Horn, K. McHugh, D.J. Booker, A.C. Wilcox, W. Brown, and M. ALVAREZ. 2014. Characterizing disturbance regimes of mountain streams. Freshwater Science 33:716-730.

Pederson, G.T., L.J. Graumlich, D.B. Fagre, T. Kipfer, AND C.C. Muhlfeld. 2010. A century of climate and ecosystem change in western Montana: what do temperature trends portend? Climatic Change 98: $133-154$.

R Development Core Team. 2017. R: a language and environment for statistical computing. R Foundation for Statistical Computing, Vienna, Austria. http://www .R-project.org

Scotti, R., F. Brardinoni, S. Alberti, P. Frattini, and G.B. Crosta. 2013. A regional inventory of rock glaciers and protalus ramparts in the central Italian Alps. Geomorphology 186:136-149.

Siebers, A.R., A. Paillex, and C.T. Robinson. 2019. Flow intermittency influences the trophic base, but not the overall diversity of alpine stream food webs. Ecography 42:1523-1535.

Thorp, J.H., AND A.P. Covich, EDITORs. 2010. Ecology and classification of North American freshwater invertebrates. 3rd edition. Academic Press, London. 1194 pp.

Tronstad, L.M., and S. Hotaling. 2017. Long-term trends in aquatic ecosystem bioassessment metrics are not influenced by sampling method: empirical evidence from the Niobrara River. Knowledge and Management of Aquatic Ecosystems 418:28-40.

Tronstad, L.M., S. Hotaling, And J.C. Bish. 2016. Longitudinal changes in stream invertebrate assemblages of Grand Teton National Park, Wyoming. Insect Conservation and Diversity 9:320-331.

WARD, J.V. 1994. Ecology of alpine streams. Freshwater Biology 32:277-294.

Waters, T.F. 1969. Subsampler for dividing large samples of stream invertebrate drift. Limnology and Oceanography $14: 813-815$.

WICKHAM, H. 2011. The split-apply-combine strategy for data analysis. 2011. Journal of Statistical Software 40: $1-29$.

Wilhelm, L., G.A. Singer, C. Fasching, T.J. Battin, and K. Besemer. 2013. Microbial biodiversity in glacierfed streams. ISME Journal 7:1651-1660.

Received 30 September 2019

Revised 14 February 2020

Accepted 19 March 2020

Published online 5 October 2020 